\title{
Optimization and Efficient Purification in Production of Brucella melitensis Recombinant HSP and TF Proteins With Low Endotoxin Contents
}

\author{
Amir Ghasemi ${ }^{1}$, Mohammad Hossein Salari ${ }^{1}$, Mohammad Reza Pourmand ${ }^{1}$, Amir Hassan \\ Zarnani ${ }^{2,3}$, Hojat Ahmadi ${ }^{4}$, Mohamad Hassan Shirazi ${ }^{1}$, Mahmood Jeddi-Tehrani ${ }^{5,{ }^{*}}$ \\ 1 Department of Pathobiology, School of Public Health, Tehran University of Medical Sciences, Tehran, IR Iran \\ 2 Nanobiotechnology Research Center, Avicenna Research Institute, ACECR, Tehran, IR Iran \\ ${ }_{4}^{3}$ Immunology Research Center, Iran University of Medical Sciences, Tehran, IR Iran \\ 4 Department of Bacterial Vaccine and Antigen Production, Pasteur Institute of Iran, Tehran, IR Iran \\ 5 Monoclonal Antibody Research Center, Avicenna Research Institute, ACECR, Tehran, IR Iran \\ ${ }^{*}$ Corresponding author:Mahmood Jeddi Tehrani, Monoclonal Antibody Research Center, Avicenna Research Institute, PO.Box 19615-1177, Tehran, IR Iran.. Tel:+98-2122432020, Fax +98- \\ 2122432021, E-mail: Mahjed@avecinna.ac,irmahjed@yahoo.com.
}

Received: Jun 20,2012; Revised: September 22, 2012; Accepted: September 30, 2012

\begin{abstract}
Background: The development of an effective subunit vaccine against brucellosis is a research area of intense. But optimization of recombinant proteins production in Escherichia coli and content of endotoxins associated with final recombinant proteins are very important.

Objectives: In the present study, expression and purification of Brucella melitensis rHSP and rTF were optimized to reduce endotoxin contaminants.

Materials and Methods: pDEST-tf and pDEST-hsp were transformed into E. coli BL21 (DE3), and then B. melitensis recombinant HSPA and TF proteins were overexpressed. Purification of these proteins was optimized to remove most of endotoxin contaminants from the end product using 0.1\% Triton X-114 in washing buffers.

Results: An endotoxin reduction of less than $0.05 \mathrm{EUmg} / 1$ was achieved with protein recovery close to an $80 \%$ yield.

Conclusions: As this new protocol requires only one step to simultaneously purify tagged proteins and eliminate endotoxins, it represents a substantial advantage in time, effort, and expense.
\end{abstract}

Keywords: Brucella melitensis; LPS; Expression; Purification; Triton

\section{Background}

Brucellosis is caused by Gram negative, facultative intracellular bacteria of the Brucella genus. Brucella melitensis Rev-1, an attenuated smooth strain used to control B. melitensis infection gives heterologous protection against other Brucella spp. and is currently considered as the best vaccine for the prophylaxis of caprine brucellosis (1). However, due to some problems related to attenuated $B$. melitensis Rev1 $(2,3)$, subunit vaccine protective against $B$. melitensis is desirable. Escherichia coli is frequently used for production of recombinant proteins because of the extensive knowledge available about this organism for both physiology and genetic characterization (4). The subsequent downstream purification of products from E. coli, remains noticeably more difficult compared to secreted proteins from eukaryotic expression organisms. Since the production of protein by E. coli in most manufacturing processes is performed intracellularly, the protein product must be selectively separated from the host proteins (5).
Proteins with up to $95 \%$ purity still contain a significant amount of endotoxins. Endotoxins are lipopolysaccharides (LPS) associated with the outer membrane of Gram-negative bacteria. The inherent toxicity of these LPSs has a profound effect on biochemical events of certain cells and can interfere with in vitro experiments (6).The threshold level of endotoxin for intravenous applications is set to 5 endotoxin units (EU) per kg body weight and hour by all pharmacopoeias (7). Because of this toxicity, the removal of even minute amounts is essential for safe administration or biological cell-based application. The following study introduces a method using of Ni-NTA agarose for recombinant protein purification by which the simultaneous removal of endotoxins is made possible.

\section{Objectives}

To test the feasibility of our protocol, we expressed, and purified $B$. melitensis rHSP and rTF proteins with very low extent of LPS. Recently we have cloned $h s p$ and $t f$ genes of

Implication for health policy/practice/ research/medical education

In this study we introduce a simple and cost effective method to remove endotoxin contaminants from recombinant proteins.

Copyright (C) 2013, Ahvaz Jundishapur University of Medical Sciences; Licensee Kowsar Ltd. This is an Open Access article distributed under the terms of the Creative Commons Attribution License (http://creativecommons.org/licenses/by/3.0), which permits unrestricted use, distribution, and reproduction in any medium, provided the original work is properly cited. 
B. melitensis by Gateway Cloning system (8).

\section{Materials and Methods}

\subsection{Expression of HSP and TF Proteins}

Recombinant pDES-tf and pDEST-hsp were transformed into competent expression host E. coli BL21 (DE3). Ampicillin-resistant colonies were grown in Luria-Bertani medium (HiMedia, India) containing $100 \mu \mathrm{g}$ of ampicillin per $\mathrm{ml}$ at $37^{\circ} \mathrm{C}$ with agitation (250 rpm) overnight. Fifteen milliliters of this culture was diluted to $500 \mathrm{ml}$ and grown until it reached an OD 600 of 0.7. Protein expression was induced by adding $1 \mathrm{mM}$ isopropyl- $\beta$ D-thiogalactopyranoside (IPTG), and incubating transformed cells for $5 \mathrm{~h}$ at $37^{\circ} \mathrm{C}$. Bacteria were pelleted by centrifugation $\left(15,000 \times \mathrm{g}, 20 \mathrm{~min}, 4^{\circ} \mathrm{C}\right)$ and frozen at $-70^{\circ} \mathrm{C}$.

\subsection{Determination of Solubility of Recombinant Proteins}

For determination of recombinant proteins solubility in PBS, pellets of five milliliter culture samples were resuspended in five milliliter PBS and bacteria were broken by sonication 3 times with $100 \%$ power at $4^{\circ} \mathrm{C}$. Lysates were centrifuged and supernatants and pellets were used in Western blots. Bacterial lysates were fractionated by electrophoresis on 12\% SDS-PAGE gel and transferred to nitrocellulose membrane (BioRad, The USA). The blot was blocked overnight at $4^{\circ} \mathrm{C}$ with PBS-0.1\% Tween 20 containing $5 \%$ nonfat dry milk and subsequently incubated with anti-6-His peroxidase (Roche, Mannheim, Germany) (1/40000) for $1 \mathrm{~h}$. Following washed in PBS-0.1\% Tween 20, bound conjugates were detected using ECL substrate (GE Healthcare, Uppsala, Sweden), and proteins were visualized by exposing the blot to autoradiography film.

\subsection{Purification and Endotoxin Removal From Re- combinant Proteins}

\subsubsection{Purification of rHSP Under Denaturing Conditions}

Bacterial cells producing rHSP were resuspended in 20 $\mathrm{ml}$ of lysis buffer (100 mM NaH2PO4, $10 \mathrm{mM}$ Tris-Cl and $8 \mathrm{M}$ urea, $10 \mathrm{mM}$ imidazole, $\mathrm{pH}$ 8.0) having urea as denaturing agent (8 M urea, $100 \mathrm{mM} \mathrm{NaH2PO} 4,10 \mathrm{mM}$ Tris-Cl, $\mathrm{pH} 8.0$ ), and then sonicated for ten 1-min cycles with $25 \%$ power at $4^{\circ} \mathrm{C}$. A suspension of $2 \mathrm{ml} \mathrm{Ni-NTA}$ agarose (Qiagen, Germany) was poured into two columns and pre equilibrated with lysis buffer.Inclusion bodies were pelleted at 20,000 $\times \mathrm{g}$ for $30 \mathrm{~min}$ at RT. Supernatant cleared lysate was loaded onto 10 columns to purify the protein by Ni-NTA agarose. The unbound proteins in the first column was washed using wash buffers $(100 \mathrm{mM} \mathrm{NaH} 2 \mathrm{PO} 4$, $10 \mathrm{mM}$ Tris-Cl and $8 \mathrm{M}$ urea, $20 \mathrm{mM}$ imidazole) and (100
$\mathrm{mM} \mathrm{NaH2PO4,} 10 \mathrm{mM}$ Tris-Cl and $8 \mathrm{M}$ urea, $40 \mathrm{mM}$ imidazole). The second column was washed with the same buffer but $0.1 \%$ TritonX-114 was added to buffers. Elution was achieved by buffer (100 mM NaH2PO4, $10 \mathrm{mM}$ Tris-Cl and $8 \mathrm{M}$ urea, $1 \mathrm{M}$ imidazole).

\subsubsection{Purification of rTF Under Native Conditions}

Expressed bacterial cells were lysed in $20 \mathrm{ml}$ of lysis buffer $(50 \mathrm{mM} \mathrm{NaH2PO} 4,300 \mathrm{mM} \mathrm{NaCl}$ and $10 \mathrm{mM}$ imidazole, $\mathrm{pH}$ 8.0) and then sonicated for ten 1-min cycles with $25 \%$ power at $4^{\circ} \mathrm{C}$. The sonicated sample was centrifuged at $20,000 \times \mathrm{g}$ for $30 \mathrm{~min}$ at $4^{\circ} \mathrm{C}$. Like rHSP, the soluble fraction of protein present in cleared lysate was purified using Ni-NTA agarose. The cleared lysate was loaded $10 \mathrm{ml}$ onto the pre equilibrated Ni-NTA agarose column with lysis buffer. Further the column was washed with wash buffers (50 mM NaH2PO4, $300 \mathrm{mM} \mathrm{NaCl}$ and $20 \mathrm{mM} \mathrm{im}$ idazole, $\mathrm{pH} 8.0$ ) and (50 mM NaH2PO4, $300 \mathrm{mM} \mathrm{NaCl}$ and $40 \mathrm{mM}$ imidazole, $\mathrm{pH} 8.0$ ) to remove the unbound nonspecific proteins and finally protein was eluted from column using elution buffer $(50 \mathrm{mM} \mathrm{NaH} 2 \mathrm{PO} 4,300 \mathrm{mM}$ $\mathrm{NaCl}$ and $1 \mathrm{M}$ imidazole, $\mathrm{pH} 8.0$ ). The second column was washed with buffers containing 0.1\% Triton X-114.

\subsubsection{Elimination of Imidazole From Recombinant Pro- teins}

To eliminate imidazole from samples, the eluted fractions were dialyzed against PBS for overnight at $4^{\circ} \mathrm{C}$.

\subsection{Endotoxin and Protein Concentration of Re- combinant Proteins}

The endotoxin content of different fractions was determined by Limulus amoebocyte lysate (Lonza, Switzerland) according to the manufacturer's instructions. Protein concentrations were determined using Bradford method. Triton X-114 content of the aqueous phase was determined by measuring the absorbance at $280 \mathrm{~nm}$.

\section{Results}

Transfection of pDEST- $h s p$ and pDEST- $t$ into $E$. coli BL21 (DE3) competent bacteria resulted in production of the respective proteins with the expected sizes as revealed by SDS-PAGE and Western blotting (Figures 1 and 2). Figures $1 \mathrm{~A}$ and $1 \mathrm{~B}$ show that rHSP and rTF were expressed in the insoluble (rHSP was seen just in pellet) and soluble fractions (rTF was seen in both supernatant and pellet) of $E$. coli cells, so they were successfully purified under denaturing and native conditions respectively (Figure 2).

The application of $0.1 \%$ Triton X-114 in the washing steps was successful to reduce endotoxins; whereas, washing steps lacking detergent were ineffective in eliminating endotoxins. In contrast to purified materials employ- 
ing the standard protocol which contained more than $10,000 \mathrm{EU} \mathrm{mg} / 1$, purified recombinant proteins treated with Triton X-114 had content of less than 0.05 endotoxin units per mg of protein (less than $99 \%$ of initial endotoxin

Figure 1. Study of Solubility and Insolubility of HSP (A) and rTF (B) With Western Blot Using Anti His-tag Monoclonal Antibody

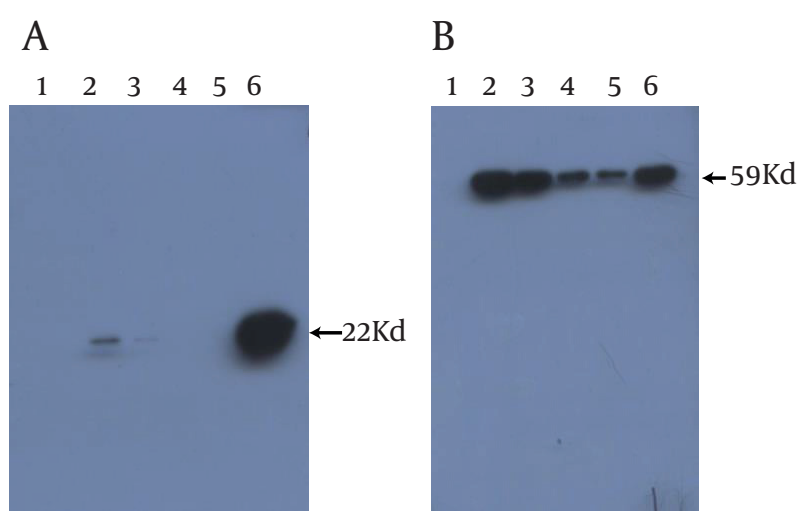

1, $5 \mu \mathrm{L} \mathrm{Bl} 21$ without Plasmid; 2, $10 \mu \mathrm{L}$ Supernatant of sonicated Bacteria; 3, $5 \mu \mathrm{L}$ Supernatant of sonicated Bacteria; 4, $2 \mu \mathrm{L}$ Supernatant of sonicated Bacteria; 5, $1 \mu \mathrm{L}$ Supernatant of sonicated Bacteria; $6,5 \mu \mathrm{L}$ pellet of sonicated Bacteria content) (Table 1). Furthermore, recovery of protein was up to $80 \%$ as compared to the standard protocol (see Figures 1 and 2 and Table 1). The elimination of endotoxins using Triton X-114 was only successful by performing the complete procedure at $4^{\circ} \mathrm{C}$.

Figure 2. SDS Electrophoresis in 12\% Polyacrylamide Gel of the Reactions Obtained by Purification of the Recombinant HSP (A) and TF (B)

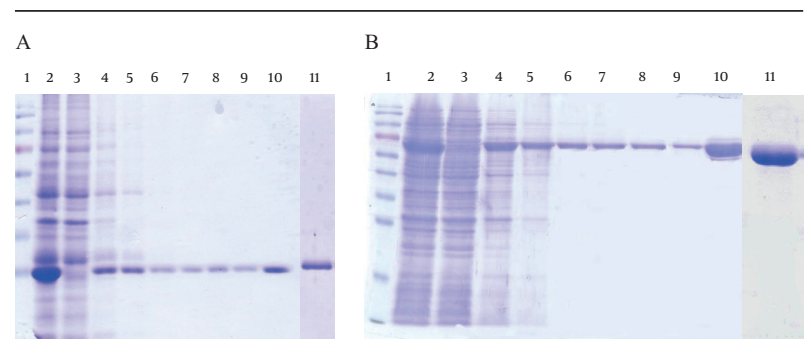

Lane 1, molecular weight marker (Fermentase SM 671); Lane 2, Lysate; Lane 3, Flow through; Lanes 4 - 6 , washed with the buffer containing $20 \mathrm{mM}$ Imidazole; Lanes 7 and 8, washed with the buffer containing $40 \mathrm{mM}$ Imidazole; Lane 9, eluted recombinant protein with modified method; Lane 10, eluted recombinant protein with standard method.

Table 1. Endotoxin Levels of Purified Recombinant Proteins

\begin{tabular}{|c|c|c|c|c|c|}
\hline Samples & pI & Triton & Purification conditions & Protein recovery, $\mathrm{mg} / \mathrm{L}$ & $\mathrm{EU}, \mathrm{mg} / \mathrm{L}$ \\
\hline \multirow[t]{2}{*}{ TF } & 4.94 & - & $\mathrm{N}$ & 15 & $>10000$ \\
\hline & & + & $\mathrm{N}$ & 12 & $<0.05$ \\
\hline \multirow[t]{2}{*}{ HSP } & 6.10 & - & $\mathrm{D}$ & 17.5 & $>10000$ \\
\hline & & + & $\mathrm{D}$ & 14 & $<0.05$ \\
\hline
\end{tabular}

\section{Discussion}

Endotoxin removal is a major issue which must be addressed for E. coli expression systems if the protein product is destined to animal study. Some commonly used techniques for removing endotoxin contaminants are ultrafiltration ( 9 ), ion exchange chromatography ( 10 ), Polymyxin B affinity chromatography (11) and LPS separation based on SDS-PAGE ( 12 ). In recent years, the interest in the use of two-phase aqueous micellar systems for the purification or concentration of biological molecules, such as proteins and viruses has been growing ( $13-15$ ). In this technique, Triton X-114 is used as nonionic surfactant micelles which separate LPS from biomolecules. In this Study, we used Triton X-114 in washing steps for removing endotoxin from recombinant proteins attaching to Ni-NTA agarose. The method used in this study, gives a product with very low extent LPS. However, twenty percent from end products were lost compared to the standard protocol (Table 1). In correlate with our results, Effi- ciency of Triton X-114 in LPS removal from recombinant proteins has been shown by Reichelt et al. ( 6 ). They have also shown that the addition of a Triton X-114, in wash buffer successfully removes more than $99 \%$ of the endotoxin contaminants.

This paper describes a rapid, cost effective, and large scale applicable alternative method for the efficient removal of endotoxins from B. melitensis recombinant HSP and TF proteins using Ni-NTA agarose together with a nonionic detergent.

\section{Acknowledgements}

None declared.

\section{Authors' Contribution}

None declared.

\section{Financial Disclosure}

None declared. 


\section{Funding/Support}

This work was supported by Tehran University of Medical Sciences the Grant No.8723, and Avicenna Research Institute the Grant No. 88-49.

\section{References}

1. Marin CM, Barberan M, Jimenez de Bagues MP, Blasco JM. Comparison of subcutaneous and conjunctival routes of Rev 1 vaccination for the prophylaxis of Brucella ovis infection in rams. Res Vet Sci.1990;48(2):209-15.

2. Blasco JM, Diaz R. Brucella melitensis Rev-1 vaccine as a cause of human brucellosis. Lancet. 1993;342(8874):805.

3. Jimenez de Bagues MP, Elzer PH, Blasco JM, Marin CM, Gamazo C, Winter AJ. Protective immunity to Brucella ovis in BALB/c mice following recovery from primary infection or immunization with subcellular vaccines. Infect Immun. 1994;62(2):632-8.

4. Sorensen HP, Mortensen KK. Advanced genetic strategies for recombinant protein expression in Escherichia coli. J Biotechnol. 2005;115(2):113-28.

5. Chen RH, Huang CJ, Newton BS, Ritter G, Old LJ, Batt CA. Factors affecting endotoxin removal from recombinant therapeutic proteins by anion exchange chromatography. Protein Expr Purif. 2009;64(1):76-81.

6. Reichelt P, Schwarz C, Donzeau M. Single step protocol to purify recombinant proteins with low endotoxin contents. Protein Expr Purif. 2006;46(2):483-8.
7. Petsch D, Anspach FB. Endotoxin removal from protein solutions. J Biotechnol. 2000;76(2-3):97-119.

8. Ghasemi A, Salari MH, Zarnani AH, Pourmand MR, Ahmadi H Shirazi MH, et al. Immunogenicity Assessment of Brucella mellitensis HSP and TF Proteins by Immunized Rabbit Serum. Iran J Allergy Asthma Immunol. 2013;12(2):192-4.

9. Sweadner KJ, Forte M, Nelsen LL. Filtration removal of endotoxin (pyrogens) in solution in different states of aggregation. Appl Environ Microbiol. 1977;34(4):382-5.

10. Shibatani T, Kakimoto T, Chibata I. Purification of high molecular weight urokinase from human urine and comparative study of two active forms of urokinase. Thromb Haemost. 1983;49(2):91-5.

11. Issekutz AC. Removal of gram-negative endotoxin from solutions by affinity chromatography.J Immunol Methods. 1983;61(3):275-81.

12. Jann B, Reske K, Jann K. Heterogeneity of lipopolysaccharides. Analysis of polysaccharide chain lengths by sodium dodecylsulfate-polyacrylamide gel electrophoresis. Eur J Biochem. 1975;60(1):239-46.

13. Mazzola PG, Lam H, Kavoosi M, Haynes CA, Pessoa A, Jr, Penna TC et al. Affinity-tagged green fluorescent protein (GFP) extraction from a clarified E. coli cell lysate using a two-phase aqueous micellar system. Biotechnol Bioeng. 2006;93(5):998-1004.

14. Rangel-Yagui CO, Lam H, Kamei DT, Wang DI, Pessoa A, Jr, Blankschtein D. Glucose-6-phosphate dehydrogenase partitioning in two-phase aqueous mixed (nonionic/cationic) micellar systems. Biotechnol Bioeng. 2003;82(4):445-56.

15. Liu CL, Kamei DT, King JA, Wang DI, Blankschtein D. Separation of proteins and viruses using two-phase aqueous micellar systems. JChromatogr B Biomed Sci Appl. 1998;711(1-2):127-38. 